\title{
Probe into the Blind Zones of Chinese EFL Students' Vocabulary Learning
}

\author{
Junyu Chen \\ Hebei United University, Tangshan, China
}

\begin{abstract}
This paper discovered the blind zones of English vocabulary learning by a series of surveys in a questionnaire. The survey involved hundreds of Chinese college learners in EFL and EL context. The findings of the research included that the avoidance of polysemants, positive words, phrasal verbs and collocations. The reasons for the avoidance were elaborated, namely, low-level motivation of learning a foreign language, inappropriate instructional strategies and information from EFL educators, and out-of-date learning materials. A number of pedagogical suggestions on how to teach vocabulary were provided.
\end{abstract}

Index Terms - vocabulary learning, EFL, blind zones

\section{INTRODUCTION}

A questionnaire in regular national universities shows a revealing fact that a majority of college students attribute English learning to memorizing new words no matter whether they are generally thought as good or less aggressive English learners or not. Eventually both the teacher and the students devote much to vocabulary explanation and memorization of new words respectively in spite of college English reform widespread all over the country. However, individual students and even quite a few college English teachers have a less satisfactory or even not qualifying performance in a survey on the basic cognition and use of some positive words and phrases, while both of the two groups do better in some more difficult lexical units. This strange phenomenon may imply inappropriate teaching instructions by teachers and incorrigibly obstinate adoption of less effective or efficient vocabulary reciting method in learning the vocabulary of the target language. This paper aims to provide implication of the necessity of reforming the vocabulary education for college English teachers. A questionnaire survey gives evidence of Chinese EFL students' blind zones in vocabulary learning.

\section{SURVEY}

The study aimed to gain a good understanding of regular college students' vocabulary learning so that weak points in vocabulary learning can be worked out. The questionnaires mainly compared among college students the use in positive words and less high frequency English words, which were to discover the blind zones among college students. These problems in vocabulary acquisition needed to be taken seriously and to be solved with speed.

\section{A. Method}

\section{Subjects}

Approximately 300 second- and third-year college students with different majors involved in the survey, among which 240 of them are non English majors and 60 are English major students. And the subjects are with different levels, technically third-year and fourth-year learners in Hebei United University, a top 10 higher institution in Hebei province, China. These subjects are from various regions around China, but an overwhelming majority of them began their English study at the age of 13 or so, that is to say, it has been at least over seven years (3 years in junior middle school and another 3 years in senior middle school and a couple of years in higher education) for them to learn English since their first contact with the foreign language.

2. Instruments

There were two main instruments employed in the study. The first and often used one was a questionnaire on the current state of college students' vocabulary learning, in particular on the learning of positive words and phrases, which are supposed to be most frequently used in the language.

The questionnaire was composed of 5 appendixes: one was about filling in blanks with the help of Chinese translation to make the sentence understandable and appropriate in meaning, which was at the highest level among the five appendixes and therefore was employed for the third-year English major students. The second appendix aimed to provide the corresponding phrases with the Chinese meaning and corresponding individual words. This part was regarded as less difficult and consequently it was conducted by the higher immediate students: second year students in college. The third one was to a great extent with the close difficulty to the second; however, it was completed by those learners with a little lower level in English achievement. Another one was designed in a simple way; it was actually a quiz on vocabulary and phrases. The subjects were required to give a corresponding separate word or phrases with the 
aid of Chinese meaning. The so-called answers to the questions were not definite, that is, close choices were also taken as acceptable answers. The last appendix was on the use of an English dictionary and some understanding of vocabulary cognition.

Twenty items were designed in the first appendix and twenty-one in the next following three appendixes and eight in the last one.

The other instrument was casual interviews between teacher and students in a rather relaxing situation. The teachers and students may sit down and have a cup of tea. This way was also playing an indispensable role in discovering the blind zones of vocabulary learning of college students. The subjects involved in the conversations were those who were with positive views on English study and honest and frank in personality.

\section{B. Findings}

TABLE 1.

RESULTS ON APPENDIX

\begin{tabular}{|l|l|l|l|}
\hline \multirow{4}{*}{ Information of subjects } & Major & \multicolumn{2}{l|}{ English } \\
\cline { 2 - 4 } & Grade & \multicolumn{2}{|l|}{ Grade Three } \\
\cline { 2 - 4 } & No. of students & \multicolumn{2}{|l|}{60} \\
\hline \multirow{4}{*}{ Result } & Appropriate answers & $2 / 20$ & $10 \%$ \\
\cline { 2 - 4 } & Acceptable choices & $5 / 20$ & $25 \%$ \\
\cline { 2 - 4 } & Poor performance & $8 / 20$ & $40 \%$ \\
\cline { 2 - 4 } & Wrong answer & $5 / 20$ & $25 \%$ \\
\hline
\end{tabular}

Appendix 1 was designed to ask the subjects to complete the sentences and dialogues with appropriate English expressions, including separate words as well as phrases. The suggested answered were expected to focus on the choices of high frequency words: carry, take, go, keep, hold, get, give, drop, make and catch. The result, however, showed a striking evidence of rather unsatisfactory answers to the twenty items which are usually everyday English. They should have shown a better performance in the questionnaire. These subjects, the juniors specializing in the English language could do well in only about 10 percent of total items, which was such a low rate that they cannot meet their needs in applying the language with high proficiency. Approximately 65 percent of sentences were completed so as to be understood by Chinese people because of the common cultural background knowledge. And even they were not able to express themselves in using the vocabulary. Please refer to Table 1.

TABLE 2.

RESULTS ON APPENDIXES 2 AND 3

\begin{tabular}{|c|c|c|c|c|c|}
\hline \multicolumn{3}{|l|}{ Appendix 2} & \multicolumn{3}{|l|}{ Appendix 3} \\
\hline No. of subjects & \multicolumn{2}{|c|}{60} & No. of subjects & \multicolumn{2}{|c|}{60} \\
\hline Major & \multicolumn{2}{|c|}{ Non-English major } & Major & \multicolumn{2}{|c|}{ Non-English majors } \\
\hline Level in English & \multicolumn{2}{|c|}{$\begin{array}{l}\text { Four-year undergraduates in } \\
\text { Grade } 2005\end{array}$} & Level in English & \multicolumn{2}{|c|}{$\begin{array}{l}\text { Three-year undergraduates in } \\
\text { Grade } 2005\end{array}$} \\
\hline Items of survey & \multicolumn{2}{|c|}{21} & Items of survey & \multicolumn{2}{|l|}{21} \\
\hline Correctness & $4 / 21$ & $19.0 \%$ & Correctness & $15 / 21$ & $71.4 \%$ \\
\hline Highest rate & $18 / 21$ & $85.7 \%$ & Highest rate & $19 / 21$ & $90.5 \%$ \\
\hline Lowest rate & 0 & $0 \%$ & Lowest rate & $2 / 21$ & $9.5 \%$ \\
\hline
\end{tabular}

In Table 2 above sees a striking comparison between two groups of subjects with different levels, to a certain extent, in exercising the vocabulary test. It is an obvious tendency that those in Appendix 3 do much better than the subjects in Appendix 2, which indicates average students demonstrate a better proficiency in individual words than mastering phrases composed of small positive words in that the second appendix was to give separate words while the third was to provide phrases.

The most noticeable trend, according to Table 2, is the very considerable gap between the average correctness of the two studies. It is a strong fact that people in doing words show 52\% more than those in doing phrase practice on average. In addition, both best and worst performances word subjects do better than phrase ones even though the latter is thought as with a lower level in applying the foreign language. The highest rate in doing separate words practice is $90.5 \%, 4.8$ higher than that in doing phrase exercise.

\section{DisCUSSION}

By way of making comparisons between word learning and phrase acquisition among 300 college students with various levels in understanding and employing the foreign language, we may make a safe conclusion that evidence showed that better proficiency in the vocabulary learning goes with better application of positive phrases and phrasal verbs what are composed of most frequently used words. As for such a case, the author would like to discuss it from the four following perspectives - linguistics, psychology, teaching and application of the language.

\section{A. On Linguistics}

Fundamental linguistic knowledge tells us that human beings acquire spoken languages prior to written languages 
(Hu, 2001). Therefore, the process of a language acquisition is supposed to start with the function of talking with people (invalid exclusive) rather than the written symbols. It is an applicable inference when it is put into the EFL acquisition. On the one hand, more often than not the words that college students are better at are less frequently used and are even sometimes low frequency vocabularies. On the other hand, there is no direct connection between language proficiency and mastering of infrequent vocabulary. This fact may remind English EFL learners of the importance of positive words and phrasal verbs in the foreign language learning process.

\section{B. On Psychology}

According to common sense, the process of learning anything should go with the nature - from easy to difficult (Carroll, 2000). Only in this way, can we go further; otherwise, it would be "The sauce is better than the fish". What is more, to approach more difficult vocabulary first will undoubtedly lead to an unbalanced vocabulary structure, will of course have a serious negative effect on the EFL acquisition.

\section{On Education}

Any educational process should follow this way: from the unknown to the known and from unfamiliar to familiar, which is applicable in learning a language. That is to say, an upward approach may be used in vocabulary education (Chen, 2007). The each word in each phrase is quite familiar to almost every primary school student, and the whole ought to be attached much importance on. On the contrary, those isolated difficult words may be distanced by its users because of their unfamiliar appearance. But the fact is not what education procedures should go, but rather.

\section{On Language Application}

It is a necessary process from unable to use a language to able to use, be it in speaking or in writing in the language. And it is nearly impossible to be able to speak difficult English when there is not a considerable vocabulary size at disposal. Furthermore, application of difficult words requires solid understanding of their connotation and denotation (Barker, 2004); it is not sufficient to know their superficial meanings alone. By contrast, a number of phrases with various changes share very flexible senses in many cases, which makes a flexible employment in various situations.

To sum up, it may be easily discovered that there exists a big gap between word and phrase learning among most college students. In that case, what we shall talk about next is what account for the gap. For the first thing, it may be an essential step to clarify the concept of vocabulary and vocabulary size. According to Longman Dictionary of Contemporary English (1995), "Vocabulary is all the words that someone knows, learns, or uses". In this definition we gain no access to have a clear division of words and phrases or to know whether phrases are part of vocabulary. This makes it possible that vocabulary learning or acquisition of college students in EFL lays much attention to the separate words alone, exclusive of phrases. By vocabulary size, it is often understood as the amount of word families a person knows or learns including "base word, its inflected words and a small number of reasonably regular derived forms (Bauer and Nation, 1993)". (Schmitt, 2002). It is strongly suggested that phrases are grouped into the vocabulary because the author does believe that a clear drawing line can play an important role in avoiding their spending too much time enriching vocabulary by means of memorizing a certain amount of individual words alone.

In order to provide some suggestions to make up the blind zones of vocabulary acquisition, it is extremely necessary to work out the characteristics of use and application of vocabulary by college students in regular universities.

The most impressive trend, according to the questionnaires may be the passive application of active words and phrases. Its manifestation is at different levels. In the first place, at the lowest level, examinees have confused most of senses and forms of the phrases such as take on, take over, take up, or turn over and the like. On separate words spelling mistakes often occur in the study. For example, "cancel" and "pretend" have been changed into the form "cancle" and "pretent" respectively. In the second place, at a higher level, they have trouble in distinguishing some vocabularies with similar semantic senses or similar pragmatics. Finally, at a high level, some examinees deliberate on employing some abstract or awkward vocabulary to show their proficiency in the language. It turns out very harmful for them to acquire idiomatic English; this phenomenon more often than not occurs on those who are good at the EFL.

Another typical characteristic is on the incomprehensibility of high frequency polysemants, that is, most college students have the tendency to know only one or a couple of senses of a word or a phrase which often appears on various occasions. They may understand turn down the radio but have trouble in making of turn somebody down. (The first "turn down" means "make the sound produced by the radio lower", while the second means "refuse".) Another instance in Appendix 1 goes as "Be careful, I don't think the branch will hold you." Around half examinees have failed in working out the word hold in spite of Chinese translation offered beside.

\section{RECOMMENDATIONS}

Based on the five essential steps in vocabulary learning (Hatch, 2001), it is high time we went by his theories and suggestions. The five essential steps are encountering new words, getting the word form, getting the word meaning, consolidating word form, meaning in memory and using the word. It is very common that many Chinese EFL students go to the second and third steps directly when learning vocabulary. Therefore, it is time to strongly encourage them to do as the theory goes because or else the words you have memorized are the castles in the air and will unavoidably lead 
to cal laps of the whole building, which means useless efforts and does harm to continue the work again.

In addition, I strongly support a "lower" the teaching objectives set in the CET syllabus particularly in the average universities of China because the vocabulary ranges from the $\mathrm{ABC}$ to some lower frequency vocabulary which are for the purposes of passing examinations only or college English education. This proves of little practical communicative significance and is has gone against with the foremost function of a language, as a lingua franca. Furthermore, the result in Appendix 5 has implied that 95 percent of the subjects have ever had the impression that complete looking up new words in a dictionary cannot solve the understanding of the passage and 25 of 60 subjects think this case often repeatedly occurs, whose discoveries of this phenomenon are mainly fall upon poor understanding of basic vocabulary. Therefore, facing up to the current state of college students' biggest blind zone in vocabulary learning, we ought to take some immediate measures to make up and to lower our goal in education should be the foremost effective step.

Simultaneously, we English educators also try our best to consolidate the understanding of basic positive vocabulary including individual words and phrases and some collocations as well, which after all are the core of the whole vocabulary. Of great interest in this doing, the author strongly suggests that we collect the polywords and conduct scientific research on the field to help students lay a solid foundation of basic category words and related polywords and then reach further.

\section{CONCLUSION}

The data from the survey in Appendix 5 show that three quarters of the subjects argued that vocabulary learning plays an indispensable role in listening, speaking, reading and writing. Their concern on this field requires every and each educator to make great efforts to improve the teaching methods and the education of the course.

\section{APPENDIX 1}

Complete the sentences with the implication in Chinese.

\begin{tabular}{|c|c|c|}
\hline No. & English sentences with missing words or phrases. & Chinese translation \\
\hline 1 & Don't get $\quad$ when you give the speech. & 演讲时别忘乎所以了。 \\
\hline 2 & Lei Feng ___ helping people. & 雷锋毕生助人。 \\
\hline 3 & Please join us as soon as you ____ your work. & 你干完工作就来和我们一起玩吧。 \\
\hline 4 & He always _ the rules. & 他总是依据规则办事。 \\
\hline 5 & Mary really ___ her mother. & 玛丽长得真的很想她妈妈。 \\
\hline 6 & He has ___ the habit of smoking. & 他不知不觉养成了抽烟的习惯。 \\
\hline 7 & $\begin{array}{l}\text { A: Would you like to go to a movie with us tonight? } \\
\text { B: I'd love to, but I'm afraid I have to __ my work; } \\
\text { tomorrow is the deadline. } \\
\text { A: What a pity! }\end{array}$ & $\begin{array}{l}\text { 今晚我们去看电影好吗? } \\
\text { 噢, 我真想去, 我得赶工作, 明天是最后期限。 } \\
\text { 真遗憾! }\end{array}$ \\
\hline 8 & Flies _____ disease. & 苍蝇传染疾病。 \\
\hline 9 & $\begin{array}{l}\text { A: Sooner or later you'll } \quad \text { the shock. } \\
\text { B: Thank you. I'm much better now. }\end{array}$ & $\begin{array}{l}\text { 迟早你会从震惊中恢复过来的。 } \\
\text { 谢谢, 我感觉好多了。 }\end{array}$ \\
\hline 10 & Now, let me___ your temperature. & 让我来给你量量体温吧。 \\
\hline 11 & Did the vaccination _____? & 疫苗起作用了吗? \\
\hline 12 & $\begin{array}{l}\text { The doctor told me that I was overtired and advised me not to } \\
\text { too much work. }\end{array}$ & 医生说我疲劳过度, 建议我不要接受太多的工作。 \\
\hline 13 & $\begin{array}{l}\text { A: They've } \quad \text { on their rent again! } \\
\text { B: I don't want to rent to them any longer. }\end{array}$ & $\begin{array}{l}\text { 他们又拖欠房租了! } \\
\text { 我再也不想租给他们了。 }\end{array}$ \\
\hline 14 & We can't ___ on my salary alone. & 单靠我的薪水我们无法维持生活。 \\
\hline 15 & $\begin{array}{l}\text { If there aren't enough chairs to ___ , some people will have } \\
\text { to stand. }\end{array}$ & 如果这儿没有足够的椅子, 一些人必须得站着了。 \\
\hline 16 & $\begin{array}{l}\text { A: It's time you } \frac{\text { your younger sister. }}{\text { B: Why should I? It's not my fault. }} \\
\text { A: You are older than she is. So you should be the first to speak } \\
\text { up. }\end{array}$ & $\begin{array}{l}\text { 你该和你妹妹和好了。 } \\
\text { 为什么是我? 又不是我的错? } \\
\text { 你比她大, 你应该主动。 }\end{array}$ \\
\hline 17 & Honey, will you ___ the phone, please? I'm in the kitchen. & 亲爱的, 能接一下电话吗？我在厨房。 \\
\hline 18 & $\begin{array}{l}\text { Will you__ the place in the queue for me while I go and } \\
\text { make a phone call? }\end{array}$ & 你能替我占着这个队中的位置吗? 我去打个电话就回来。 \\
\hline 19 & $\begin{array}{l}\text { A: Be careful, I don't think the branch will } \_ \text {you. } \\
\text { B: I'm not sitting on it. I'm just leaning on it. }\end{array}$ & $\begin{array}{l}\text { 小心点, 我可不认为这个树枝能撑住你。 } \\
\text { 我没坐上去, 只是靠着它。 }\end{array}$ \\
\hline 20 & $\begin{array}{l}\text { A: Somebody should } \quad \text { that Rhoda's ill. } \\
\text { B: OK. We'll get started without her. }\end{array}$ & $\begin{array}{l}\text { 应该有人捎信告诉我们罗达生病一事。 } \\
\text { 那好, 她不来了，我们开始吧。 }\end{array}$ \\
\hline
\end{tabular}




\section{APPENDIX 2}

Please give out the phrases with the hint of Chinese meaning and the meanings of separate words.

\begin{tabular}{|c|c|c|c|}
\hline No. & Separate words（单个单词） & Phrases (短语) & Chinese meaning \\
\hline 1 & explode & & 爆炸 \\
\hline 2 & quarrel (with) & & 与...争吵 \\
\hline 3 & recruit & & 征召...入伍 \\
\hline 4 & pretend & & 假装 \\
\hline 5 & erupt & & (火山等) 喷发 \\
\hline 6 & visit & & （顺路）拜访 \\
\hline 7 & inspect & & 检查,审查,调查 \\
\hline 8 & reject, refuse & & 拒绝 \\
\hline 9 & succeed & & 成功 \\
\hline 10 & represent & & 代表 \\
\hline 11 & imply & & 暗指, 意旨 \\
\hline 12 & postpone & & 推迟 \\
\hline 13 & imply & & 意旨, 暗指 \\
\hline 14 & participate & & 参与, 参加 \\
\hline 15 & experience & & 经历 \\
\hline 16 & produce & & 提出 \\
\hline 17 & tolerate & & 容忍, 忍受 \\
\hline 18 & interrupt & & 打断, 插嘴 \\
\hline 19 & understand & & 理解,明白 \\
\hline 20 & flatter & & 巴结, 奉承 \\
\hline 21 & cancel & & 取消 \\
\hline
\end{tabular}

\section{APPENDIX 3}

Fill in the table by writing down the separate words with the help of corresponding phrases and Chinese meaning.

\begin{tabular}{|c|c|c|c|}
\hline No. & Separate words（单个单词） & Phrases（短语） & Chinese meaning \\
\hline 1 & & break out & 爆炸 \\
\hline 2 & & fall out (with) & 与...争吵 \\
\hline 3 & & call up & 征召...入伍 \\
\hline 4 & & make believe & 假装 \\
\hline 5 & & break out & (火山等) 喷发 \\
\hline 6 & & drop by & （顺路）拜访 \\
\hline 7 & & look into & 检查,审查,调查 \\
\hline 8 & & turn down & 拒绝 \\
\hline 9 & & make it & 成功 \\
\hline 10 & & stand for & 代表 \\
\hline 11 & & get at & 暗指, 意旨 \\
\hline 12 & & put off & 推迟 \\
\hline 13 & & get at & 意旨, 暗指 \\
\hline 14 & & take part in & 参与, 参加 \\
\hline 15 & & go through & 经历 \\
\hline 16 & & come up with, put forward & 提出 \\
\hline 17 & & put up with & 容忍, 忍受 \\
\hline 18 & & cut off, cut in & 打断, 插嘴 \\
\hline 19 & & make of & 理解 \\
\hline 20 & & make up to & 巴结, 奉承 \\
\hline 21 & & call off & 取消 \\
\hline
\end{tabular}




\section{APPENDIX 4}

Translate the Chinese expressions and write them down in the column of English expressions.

\begin{tabular}{|l|l|l|}
\hline No. & English expressions & Chinese meaning \\
\hline 1 & & 爆炸 \\
\hline 2 & & 与...争吵 \\
\hline 3 & & 征召...入伍 \\
\hline 4 & & 假装 \\
\hline 5 & & (火山等) 喷发 \\
\hline 6 & & (顺路) 拜访 \\
\hline 7 & & 检查,审查,调查 \\
\hline 8 & & 拒绝 \\
\hline 9 & & 成功 \\
\hline 10 & & 代表 \\
\hline 11 & & 暗指, 意旨 \\
\hline 12 & & 推迟 \\
\hline 13 & & 意旨, 暗指 \\
\hline 14 & & 参与, 参加 \\
\hline 15 & & 经历 \\
\hline 16 & & 提出 \\
\hline 17 & & 容忍, 忍受 \\
\hline 18 & & 打断, 插嘴 \\
\hline 19 & & 理解 \\
\hline 20 & & 巴结, 奉承 \\
\hline 21 & & 取消 \\
\hline
\end{tabular}

\section{APPENDIX 5}

Please complete the survey. Thanks for helping.

1. 如果你有英语词典, 那么它 (或它们) 是

\begin{tabular}{|l|l|l|l|l|}
\hline \multirow{2}{*}{ 序号 } & \multirow{2}{*}{ 词典名称 } & \multicolumn{3}{|l|}{ 词典使用情况 } \\
\hline & 经常使用 & 偶尔查阅 & 很少使用 \\
\hline 1 & 牛津高阶英汉双解词典 & & & \\
\hline 2 & 牛津中阶英汉双解词典 & & & \\
\hline 3 & 牛津初阶英汉双解词典 & & & \\
\hline 4 & 朗文高阶英汉双解词典 & & & \\
\hline 5 & 朗文中阶英汉双解词典 & & & \\
\hline 6 & 朗文初阶英汉双解词典 & & & \\
\hline 7 & 新英汉词典 & & & \\
\hline 8 & 四级 (六级) 词汇小词典 (或类似) & & & \\
\hline 9 & 其他 (请注明)__ & & & \\
\hline
\end{tabular}

2. 词典对于你的用途主要是什么?
A) 查单词的词义
B) 查找例句
C) 背词典学英语
D) 查找词组搭配
E) 查习语
F) 查其他内容 (请注明)

3. 在英语学习过程中, 您是否有过这样的体会: 查完一篇文章中所有的生词, 理解其内容仍然有困难?
A) 有。
B) 没有。
A) 大多数课文都如此
B) 经常有此状况
C) 偶尔如此
D) 基本没有这样的情况

1) 如果有 3. 的情况, 那么这种情况发生的频率怎样?

2) 如果有 3. 的情况, 那么您认为是什么原因?

A) 生词理解深度不够 
B) 其他基本词汇理解有偏差

C) 词组搭配的理解有碍

D) 其他原因 (请注明)

4. 您是否希望在您的写作中用上一些较为生僻的词汇?

5. 您是否认为作文中只有非常普通的词汇，没有大词，那么您认为会影响此文的得分吗?

6. 您是否暗自崇拜过高深莫测的英文材料，（所谓高深莫测就是您看不懂的文章）？

7. 您是否会怀疑满篇是高频词汇的文章作者的语言功底呢?

8. 您认为写出优秀作文的关键是什么?

\section{REFERENCES}

[1] Barker, T. (2004). CELEA Journal. In Li Lan (ed.). Teaching Vocabulary via Semantic Relationship of Phrasal Verbs Vol. 27. (pp. 54-58). Beijing: Foreign Language Teaching and Research Press; Brooks/Thomson Learning Asia.

[2] Barker, T. (2004). CELEA Journal. In Yang Jian (ed.). Use and Helpfulness of Chinese EFL Students' Vocabulary Learning Strategies Vol. 27. (pp. 54-58). Beijing: Foreign Language Teaching and Research Press; Brooks/Thomson Learning Asia.

[3] Carroll, D. W. (2000). Psychology of Language. Beijing: Foreign Language Teaching and Research Press; Brooks/Thomson Learning Asia.

[4] Chen, J. (2007). On How to Solve the Problem of the Avoidance of Phrasal Verbs in the Chinese Context. Adelaide: International Education Journal.

[5] Hatch, E. \& Brown, C. (2001). Vocabulary, Semantics and Language Education. Beijing: Foreign Language Teaching and Research Press; Cambridge University Press.

[6] Hu, Z. (2001). An Introduction to linguistics. Beijing: Beijing University Press.

[7] Schmitt, N. \& McCarthy, M. (2002). Vocabulary: Description, Acquisition and Pedagogy. Shanghai: Shanghai Foreign Language Education Press.

Junyu Chen was born in Tangshan, China in 1977. She received her master's degree in English Education from the University of South Australia, Australia in 2007.

She is currently a lecturer in the College of Foreign Languages, Hebei United University, Tangshan, China. Her research interests include English education and culture. Her particular interest consists in the combination of Chinese traditional culture and TESOL. 